\title{
RT-PCR Detection of Five Quarantine Plant RNA Viruses Belonging to Poty- and Tospoviruses
}

\author{
Jong-Seung Lee ${ }^{1}$, Won Kyong Cho ${ }^{1}$, Hong-Soo Choi ${ }^{2}$ and Kook-Hyung Kim ${ }^{1 *}$ \\ ${ }^{\prime}$ Department of Agricultural Biotechnology and Plant Breeding and Genomics Institute, College of Agriculture and Life Sciences, \\ Seoul National University, Seoul 151-921, Korea \\ ${ }^{2}$ Department of Agricultural Biology, National Academy of Agricultural Science, Rural Development Administration, Suwon 441- \\ 707, Korea \\ (Received on July 13, 2011; Revised on August 3, 2011; Accepted on August 3, 2011)
}

In order to detect quarantine plant viruses, we developed reverse transcription-polymerase chain reaction (RT-PCR) primer pairs for five single-stranded (ss) plant RNA viruses that are not currently reported in Korea but could be potential harmful plant viral pathogens. Three viruses such as Chilli veinal mottle virus (ChiVMV), Colombian datura virus (CDV), and Tobacco etch virus (TEV) belong to the genus Potyvirus while Chrysanthemum stem necrosis virus (CSNV) and Iris yellow spot virus (IYSV) are members of the genus Tospovirus. To design RT-PCR primers, we used reported gene sequences corresponding to the capsid protein and polyprotein for ChiVMV, CDV, and TEV while using nucleocapsid protein regions for CSNV and IYSV. At least two different primer pairs were designed for each virus. Fifteen out of $\mathbf{1 6}$ primer pairs were successfully applied in detection of individual quarantine virus with high specificity and efficiency. Taken together, this study provides a rapid and useful protocol for detection of five quarantine viruses.

Keywords : Potyvirus, Quarantine, RT-PCR, ssRNA virus, Tospvirus

In recent years, global climate change impacts on our enviromental systems including agriculture and ecosystem. Increased average temperature affects survival rates of insect vectors which are the main factors promoting incidence and spread of plant viral diseases (Garrett et al., 2006). The climiate of the Korean pennisula becomes warmer than before and several unexpected diseases led to dramatic economic losses in many important crops, vegetables, and fruits (Choi et al., 2009). In addition, a large amount of agricultural products are being imported from the world to stabilize prices and this will be accelarated by Free Trade

\footnotetext{
*Corresponding author.

Phone) +82-2-880-4677, FAX) +82-2-873-2317

E-mail)kookkim@snu.ac.kr
}

Agreement (FTA) between Korea and other countries including the United States and European Union. Eventually, the possibility of introduction of foreign plant viruses via imported plants and foods becomes increasing. Moreover, the changed chlimate in Korea will be suitable for foreign viruses to replicate and spread in new host plants (Elena et al., 2011). For these reasons, the National Plant Quarantine Service (NPQS) in Korea needs to strengthen plant quarantine. To control inflow of quarantine plant viruses, effective monitoring methods are required. Of known techniques, reverse transcription-polymerase chain reaction (RT-PCR) is the rapid tool with highly specific and sensitive for detection of individual virus (Lee et al., 2011; Park and Kim, 2004). In a close cooperation with the NPQS, we are currently developing RT-PCR based detection system for major quarantine plant viruses and have reported RT-PCR detection methods for quarantine plant viruses infecting fruit trees and the family Cucurbitaceae or Solanaceae (Lee et al., 2011; Park and Kim, 2004).

In a series of detecting quarantine plant viruses, five additional single-strand RNA viruses causing significant economic problems to many vegetables and flowering plants were further chosen in this study. These viruses include Chilli veinal mottle virus (ChiVMV; Hwang et al., 2009), Colombian datura virus (CDV; Salamon and Palkovics, 2005), Tobacco etch virus (TEV; Carrasco et al., 2007), Chrysanthemum stem necrosis virus (CSNV; Bezerra et al., 1999), and Iris yellow spot virus (IYSV; Pappu et al., 2006) (Table 1). ChiVMV, CDV and TEV are positivestrand RNA viruses and consist of one RNA segment belonging to the genus Potyvirus, family Potyviridae (Table 1). In contrast, CSNV and IYSV are negative-strand RNA viruses and composed of three RNA segments belonging to the genus Tospovirus, family Bunyaviridae (Table 1).

All three potyviruses can infect plants in the Solanaceae family (Table 1). For instance, ChiVMV is one of major virus infecting chilli pepper causing mosaic, mottling, leaf distortion, vein etching, yellowing, and stunting symptoms. 
Since the first identification of CDV from Brugmansia in Colombia in the late 1960s, it is quickly spread from South America such as Colombia, Ecuador, and Bolivia to Europe by imported plant materials. CDV infects angel trumpets (Brugmansia spp.), cape gooseberry (Physalis peruviana), and pepino (Solanum muricatum) in Hungary (Salamon and Palkovics, 2005). TEV is one of well characterized plant virus in the genus Potyvirus and many plants including pepper, tomato, and tobacco species in the Solanaceae can be infected by TEV. TEV causes mosaic and dark green vain banding in infected pepper leaves and cause stunted and misshapened fruit formation. CSNV has been firstly reported in Netherlands and Brazil where chrysanthemum is largely cultivated. Symptoms of CSNV in chrysanthemum are necrotic local lesions with concentric yellow spots on leaves leading to the death of most plants (Bezerra et al., 1999). IYSV infects mostly Allium species like onion, ornamentals like iris, and lisianthus (Diaz-Montano et al., 2011). In particular, the initial identification of IYSV in Brazil, IYSV is one of serious viral diseases in many onion producing countries. Symptoms of IYSV composed of yellow or straw colored diamond shaped lesions on the scape or leaves in onion plants (Diaz-Montano et al., 2011). All three potyviruses including ChiVMV, CDV, and TEV are principally transmitted by the aphid species in a non-persistent manner. They can also be transmitted by mechanical inoculation and grafting but not by seeds. Both CSNV and IYSV are transmitted by the family Thripidae including Frankliniella occidentalis and Frankliniella schultzei for CSNV (Bezerra et al., 1999) and Thrips tabaci for IYSV (Diaz-Montano et al., 2011) in a persistent manner.

To design RT-PCR primer pairs, we utilized known available RNA sequences for each virus deposited in National Center for Biotechnology Information (NCBI). In case of ChiVMV, CDV, and TEV, RNA sequences encoding capsid protein $(\mathrm{CP})$ and polyprotein were retrieved for primer design due to high conservancy within the virus species (Table 2). As for the RT-PCR detection of CSNV and IYSV, gene regions corresponding to non-structural and nucleocapsid protein (NCP) genes were used (Table 2). At least two different primer pairs for individual gene were designed and the lengths of primer pairs were varied to distinguish quarantine viruses easily (Table 2 ). For instance, the lengths of PCR fragments to detect the CP of ChiVMV are $389 \mathrm{bp}$ and $550 \mathrm{bp}$, and TEV can be detected with fragments ranged from $259 \mathrm{bp}$ and $529 \mathrm{bp}$. Overall, the size of amplified PCR fragments ranges from $236 \mathrm{bp}$ to $662 \mathrm{bp}$. The information for RT-PCR primers can be found in Table 2. All primers were synthesized from Bioneer Corp. (Korea). We imported all five plant ssRNA viruses from DSMZ $\mathrm{GmbH}$, plant virus collection (Braunschweig, Germany). The imported samples were either dried plant materials or frozen total nucleic acids deposited at $-20^{\circ} \mathrm{C}$. All processes related to the import of quarantine viruses were done after permission from NPQS and all experiments were carried out in restricted area to prevent virus outflow. Total RNAs derived from virus infected plant tissues as well as healthy leaves of Nicotiana benthamiana and tomato were prepared by extraction with Trizol Reagent ${ }^{\circledR}$ (Molecular Research Center, Inc., USA) followed by phenol:chloroform:isoamylalcohol (25:24:1) extraction and ethanol precipitation according to the previous study (Park and Kim, 2004). The extracted total RNAs were analyzed by agarose gel electrophoresis and subjected to the NanoPhotometer ${ }^{\mathrm{TM}}$ (Implen $\mathrm{GmbH}$, Germany) to measure quality and quantity of the RNAs, respectively. As shown Fig. 1A, the quality and quantity of extracted total RNAs were good enough to carry out RT-PCR indicating high quality of isolated RNAs. The cDNAs were synthesized using the extracted total RNAs and PCRs were conducted using the cDNA as a template. Syntheses of cDNAs and RT-PCR reactions were conducted as described previously (Lee et al., 2011). In brief, complementary DNAs (cDNAs) were synthesized by using

Table 1. List of plant viruses assayed for quarantine

\begin{tabular}{|c|c|c|c|c|c|}
\hline Plant virus name & Genus & Family & Type & $\begin{array}{l}\text { No. of RNA } \\
\text { fragments }\end{array}$ & Host plants \\
\hline $\begin{array}{c}\text { Colombian datura virus } \\
\text { (CDV) }\end{array}$ & Potyvirus & Potyviridae & $\begin{array}{l}\text { SsRNA } \\
(+) \text {-strand }\end{array}$ & 1 & $\begin{array}{l}\text { Tomato, pepino, tobacco, } \\
\text { cape gooseberry, petunia }\end{array}$ \\
\hline $\begin{array}{l}\text { Chilli veinal mottle virus } \\
\text { (ChiVMV) }\end{array}$ & Potyvirus & Potyviridae & $\begin{array}{l}\text { ssRNA } \\
(+) \text {-strand }\end{array}$ & 1 & Pepper, tobacco, nightshade \\
\hline $\begin{array}{c}\text { Tobacco etch virus } \\
\text { (TEV) }\end{array}$ & Potyvirus & Potyviridae & $\begin{array}{l}\text { ssRNA } \\
(+) \text {-strand }\end{array}$ & 1 & $\begin{array}{l}\text { Pepper, tomato, tobacco, nightshade, } \\
\text { pigweed, ground cherry }\end{array}$ \\
\hline $\begin{array}{l}\text { Chrysanthemum stem } \\
\text { necrosis virus (CSNV) }\end{array}$ & Tospovirus & Bunyaviridae & $\begin{array}{l}\text { ssRNA } \\
(-) \text {-strand }\end{array}$ & 3 & Chrysanthemum, tomato \\
\hline $\begin{array}{l}\text { Iris yellow spot virus } \\
\text { (IYSV) }\end{array}$ & Tospovirus & Bunyaviridae & $\begin{array}{l}\text { ssRNA } \\
(-) \text {-strand }\end{array}$ & 3 & $\begin{array}{l}\text { Onions, garlic, leek, iris, lisianthus, } \\
\text { jimsonweed, tobacco, redroot pigweed }\end{array}$ \\
\hline
\end{tabular}


Table 2. Nucleotide sequences of oligonucleotide primers used for RT-PCR to detect five quarantine plant viruses

\begin{tabular}{|c|c|c|c|c|c|c|c|c|}
\hline Index & Name & $\begin{array}{l}\text { Amplified } \\
\text { region }\end{array}$ & $\begin{array}{c}\text { Nucleotide } \\
\text { accession No. }\end{array}$ & Primer sequences & Length & $\begin{array}{l}\mathrm{Tm} \\
\left({ }^{\circ} \mathrm{C}\right)\end{array}$ & $\begin{array}{l}\text { Expected } \\
\text { size }\end{array}$ & $\begin{array}{c}\text { RT-PCR } \\
\text { result }\end{array}$ \\
\hline 1 & CDV-CP1_F & capsid protein & FJ821796 & 5'-GGTGTCTGGACTATGATGGATG-3' & 22 & 52.9 & $420 \mathrm{bp}$ & Specific \\
\hline 2 & CDV-CP1_R & capsid protein & FJ821796 & 5'-ССТCTAACCTTGACGCACACC-3' & 21 & 55.8 & $420 \mathrm{bp}$ & Specific \\
\hline 3 & $\mathrm{CDV}-\mathrm{CP} 2-\mathrm{F}$ & capsid protein & FJ821796 & 5'-CTGCAGCAATTCGAAACAACAC-3' & 22 & 56.9 & $281 \mathrm{bp}$ & Specific \\
\hline 4 & $\mathrm{CDV}-\mathrm{CP} 2 \_\mathrm{R}$ & capsid protein & FJ821796 & 5'-GTAAATACTGACTAACGCCCTTCTG-3' & 25 & 54.5 & $281 \mathrm{bp}$ & Specific \\
\hline 5 & CDV-Poly1_F & polyprotein & AB179622 & 5'-CAAGATCGAGATGTGAATGCTG-3' & 22 & 54.5 & $662 \mathrm{bp}$ & Specific \\
\hline 6 & CDV-Poly1_R & polyprotein & AB179622 & 5'-GTGTGACGTTCGGTATCCTCTTC-3' & 23 & 56.2 & $662 \mathrm{bp}$ & Specific \\
\hline 7 & CDV-Poly2_F & polyprotein & AB179622 & 5'-CTGTGCAAGCATCATAGAGTCG-3' & 22 & 54.8 & $498 \mathrm{bp}$ & Specific \\
\hline 8 & CDV-Poly2_R & polyprotein & $\mathrm{AB} 179622$ & 5'-GGTTTGTAGTTCAGCAGATGGTC-3' & 23 & 54.2 & $498 \mathrm{bp}$ & Specific \\
\hline 9 & ChiVMV-CP1_F & capsid protein & NC_005778 & 5'-CAAGCTCAGCCACAGTCTCGTC-3' & 22 & 58.6 & $550 \mathrm{bp}$ & Specific \\
\hline 10 & ChiVMV-CP1_R & capsid protein & NC_005778 & 5'-CGCGCTAATGACATATCGGTAAG-3' & 23 & 57.5 & $550 \mathrm{bp}$ & Specific \\
\hline 11 & ChiVMV-CP2_F & capsid protein & NC_005778 & 5'-CTGAATGGATTGATGGTTTGGTG-3' & 23 & 57.7 & $389 \mathrm{bp}$ & Specific \\
\hline 12 & ChiVMV-CP2_R & capsid protein & NC_005778 & 5'-GTGCCTACCCTACCGTCCAGTC-3' & 22 & 58.3 & $389 \mathrm{bp}$ & Specific \\
\hline 13 & ChiVMV-Poly1_F & polyprotein & EF213685 & 5'-CTCTGAGGGGAAGGCACCATAC-3' & 22 & 58.4 & $443 \mathrm{bp}$ & Specific \\
\hline 14 & ChiVMV-Poly1_R & polyprotein & EF213685 & 5'-CAGGGGCATAATCAAGAAGGTG-3' & 22 & 57.1 & $443 \mathrm{bp}$ & Specific \\
\hline 15 & ChiVMV-Poly2_F & polyprotein & EF213685 & 5'-GCGGTATGCTTTCGATTTCTATG-3' & 23 & 56.8 & $404 \mathrm{bp}$ & Specific \\
\hline 16 & ChiVMV-Poly2_R & polyprotein & EF213685 & 5'-GCTAGAACGGGCGGGGATAC-3' & 20 & 59.2 & $404 \mathrm{bp}$ & Specific \\
\hline 17 & TEV-CP1_F & capsid protein & DQ871317 & 5'-CGCTATGGCCACAAAACTTCAAT-3' & 23 & 58.9 & $339 \mathrm{bp}$ & Specific \\
\hline 18 & TEV-CP1_R & capsid protein & DQ871317 & 5'-GTCATAATTTGCCTCAGTGTTGG-3' & 23 & 55 & $339 \mathrm{bp}$ & Specific \\
\hline 19 & TEV-CP2_F & capsid protein & DQ871317 & 5'-CTAAATGGATTTATGGTGTGGTG-3' & 23 & 52.6 & $391 \mathrm{bp}$ & Specific \\
\hline 20 & TEV-CP2_R & capsid protein & DQ871317 & 5'-CAGTACCCACGTTGCCATCA-3' & 20 & 56.3 & $391 \mathrm{bp}$ & Specific \\
\hline 21 & TEV-Poly1_F & polyprotein & NC_001555 & 5'-GACCCAAATGAAGGATACGATAAG-3' & 24 & 54.7 & $259 \mathrm{bp}$ & Specific \\
\hline 22 & TEV-Poly1_R & polyprotein & NC_001555 & 5'-GTCTCTTCGTTGGGTGCTTTAG-3' & 22 & 54.5 & $259 \mathrm{bp}$ & Specific \\
\hline 23 & TEV-Poly2_F & polyprotein & NC_001555 & 5'-GTGTGCAAAGAAATTCCAGACTC-3' & 23 & 54.3 & $529 \mathrm{bp}$ & Specific \\
\hline 24 & TEV-Poly2_R & polyprotein & NC_001555 & 5'-CACCACCAATTAACACAGACAAAG-3' & 24 & 55 & $529 \mathrm{bp}$ & Specific \\
\hline 25 & CSNV-NCP1_F & $\begin{array}{l}\text { nucleocapsid } \\
\text { protein }\end{array}$ & AB438998 & 5'-GCGGAATACTCTGCACGACTTG-3' & 22 & 58.4 & $601 \mathrm{bp}$ & Specific \\
\hline 26 & CSNV-NCP1_R & $\begin{array}{l}\text { nucleocapsid } \\
\text { protein }\end{array}$ & AB438998 & 5'-GCTCTTTGTGCTTTGAATCCTG-3' & 22 & 55.4 & $601 \mathrm{bp}$ & Specific \\
\hline 27 & CSNV-NCP2_F & $\begin{array}{l}\text { nucleocapsid } \\
\text { protein }\end{array}$ & AB438998 & 5'-CTTACGGGCTTAGCTTGAATG-3' & 21 & 53.3 & $300 \mathrm{bp}$ & Specific \\
\hline 28 & CSNV-NCP2_R & $\begin{array}{l}\text { nucleocapsid } \\
\text { protein }\end{array}$ & AB438998 & 5'-CTCCTTTCATTCTTGGGTCAC-3' & 21 & 52.4 & $300 \mathrm{bp}$ & Specific \\
\hline 29 & IYSV-NCP1_F & $\begin{array}{l}\text { nucleocapsid } \\
\text { protein }\end{array}$ & AF067070 & 5'-TCTGGTGAGTGCATATGGTTTGA-3' & 23 & 56.7 & $420 \mathrm{bp}$ & $\begin{array}{l}\text { Un- } \\
\text { specific }\end{array}$ \\
\hline 30 & IYSV-NCP1_R & $\begin{array}{l}\text { nucleocapsid } \\
\text { protein }\end{array}$ & AF067070 & 5'-CTTGGAGGGATTCTTGGGTTTAG-3' & 23 & 56.9 & $420 \mathrm{bp}$ & $\begin{array}{l}\text { Un- } \\
\text { specific }\end{array}$ \\
\hline 31 & IYSV-NCP2_F & $\begin{array}{l}\text { nucleocapsid } \\
\text { protein }\end{array}$ & AF067070 & 5'-GGCGGTCCTCTCATCTTACTG-3' & 21 & 55 & $236 \mathrm{bp}$ & Specific \\
\hline 32 & IYSV-NCP2_R & $\begin{array}{l}\text { nucleocapsid } \\
\text { protein }\end{array}$ & AF067070 & 5'-GAAGTTCCAGGAGTGCATTTAGTC-3' & 24 & 54.9 & $236 \mathrm{bp}$ & Specific \\
\hline
\end{tabular}

M-MLV reverse transcriptase (RT) and RT-PCR was performed for 30 cycles using a Peltier Thermal Cycler (MJ Research, USA). Five $\mu$ l of amplified PCR products were separated on $1 \%$ agarose gel by electrophoresis, visualized by staining with $0.5 \mu \mathrm{g} / \mathrm{ml} \mathrm{EtBr}$, and observed under UV illumination.

For first PCR reaction, we used $53^{\circ} \mathrm{C}$ and $30 \mathrm{sec}$ as an annealing temperature and time. Of designed 16 primer pairs, 15 primer pairs showed successful PCR amplification except IYSV-NCP1 which displayed two amplified PCR products (Fig. 1A). In case of CDV detection, primer pairs for CDV-CP2 and CDV-Poly1 amplified one specific band with high amount of transcripts but the band intensity for CDV-CP1 is relatively weak suggesting that CDV-CP1 primer pair was not optimally bound to target CDV RNA sequences (Fig. 1B).

To optimize annealing temperature for individual primer pair, gradient PCR was conducted at three different temper- 

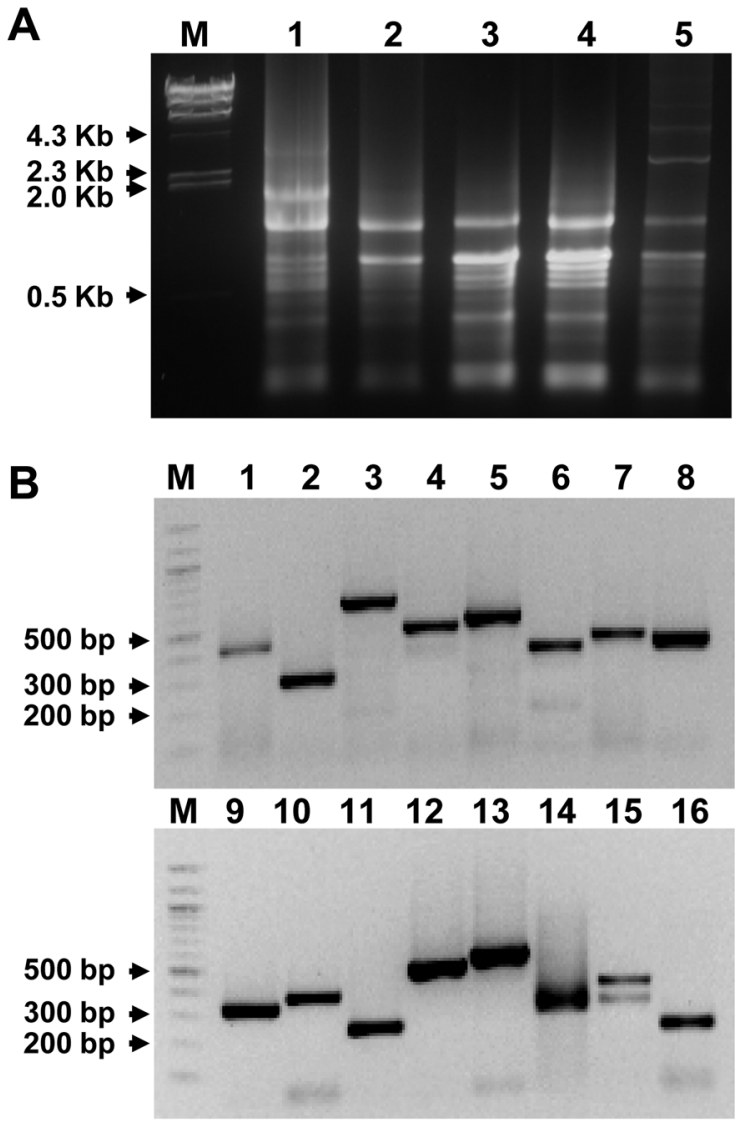

Fig. 1. Isolation of total RNAs and RT-PCR using newly developed primer pairs. (A) Total RNAs extracted from virus infected plant leaves. $\mathrm{M}$ indicates lamda DNA molecular marker digested with HindIII $(600 \mathrm{ng} / 5 \mu \mathrm{l})$. Lanes $1-5$ represent RNA extracted from CDV, ChiVMV, TEV, CSNV, and IYSV infected samples, respectively. (B) RT-PCR using following primer pairs. Lane 1, CDV-CP1; Lane 2, CDV-CP2; Lane 3, CDV-Poly1; Lane 4, CDV-Poly2; Lane 5, ChiVMV-CP1; Lane 6, ChiVMV-CP2; Lane 7, ChiVMV-Poly1; Lane 8, ChiVMV-Poly2; Lane 9, TEVCP1; Lane 10, TEV-CP2; Lane 11, TEV-Poly1; Lane 12, TEVPoly2; Lane 13, CSNV-NCP1; Lane 14, CSNV-NCP2; Lane 15, IYSV-NCP1; Lane 16, IYSV-NCP2.

atures including $52^{\circ} \mathrm{C}, 55^{\circ} \mathrm{C}$, and $57^{\circ} \mathrm{C}$ (Fig. 2). Interestingly, as annealing temperature goes up, the amount of amplified PCR was increased. At $52^{\circ} \mathrm{C}$, except three primerpairs including ChiVMV-CP1, TEV-Poly2, and CSNVNCP1, the intensity of band was rather weak. Especially, primer pairs for CDV-CP1 and IYSV-NCP2 could hardly amplify PCR products. At both $55^{\circ} \mathrm{C}$ and $57^{\circ} \mathrm{C}$ for annealing temperature, we detected additional unspecific bands from CDV-Poly1 and ChiVMV-CP2 primer pairs which might be amplified by binding to other genes in host plants. To test such hypothesis, we extracted total RNAs from leaves of virus free tomato and $N$. benthamiana and synthesized cDNAs. Using the cDNAs derived from virus free plants as templates, we carried out RT-PCR at $55^{\circ} \mathrm{C}$. All
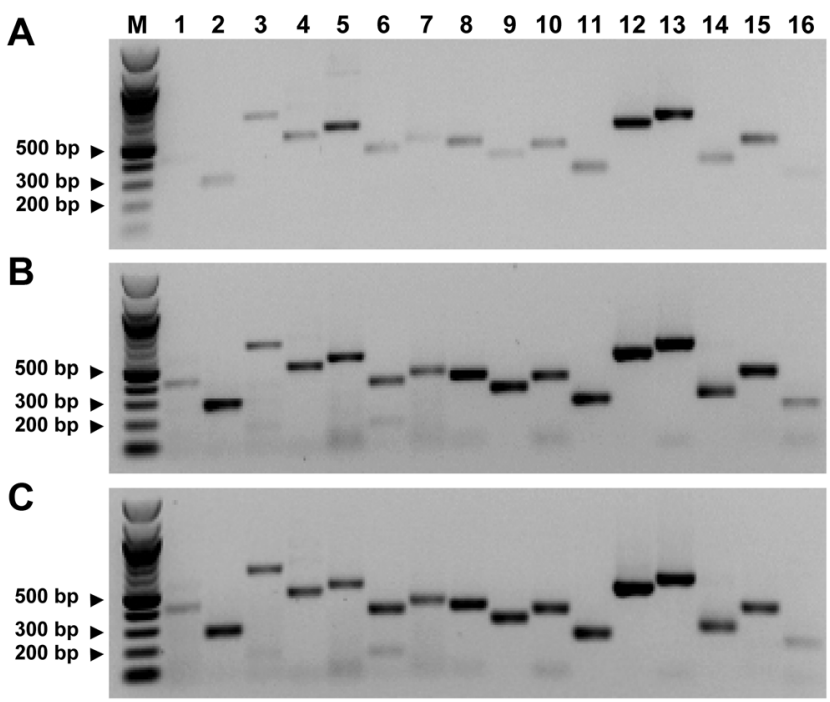

Fig. 2. Gradient RT-PCR to optimize specificity of each primer pair. $\mathrm{M}$ indicates $100 \mathrm{bp}$ DNA ladder purchased from NEB, UK. PCR products from three different annealing temperatures including $52^{\circ} \mathrm{C}(\mathrm{A}), 55^{\circ} \mathrm{C}(\mathrm{B})$, and $57^{\circ} \mathrm{C}(\mathrm{C})$ were shown. Lanes 1, CDV-CP1; 2, CDV-CP2; 3, CDV-Poly1; 4, CDV-Poly2; 5, ChiVMV-CP1; 6, ChiVMV-CP2; 7, ChiVMV-Poly1; 8, ChiVMVPoly2; 9, TEV-CP1; 10, TEV-CP2; 11, TEV-Poly1; 12, TEVPoly2; 13, CSNV-NCP1; 14, CSNV-NCP2; 15, IYSV-NCP1; 16, IYSV-NCP2.

primer pairs displayed only one expected band in virus infected samples but not in virus free plant samples (Fig. 3). Thus, it is likely that the amplified unspecific bands were derived not from nonspecific binding of designed primer pairs but from target plant virus. We assume that the designed primer pairs could also bind to not only target sequences but also other nucleotide regions or degraded RNA genomes of the quarantine plant viruses. Nevertheless, we can apply the designed primer pairs to detect quarantine viruses since these primers can amplify expected size DNA fragments as major amplification PCR products. In many case, viral proteins in same genus are highly homologous. Thus, it is likely that the designed primer pairs for $\mathrm{CP}$ or polyprotein can amplify other viral genes in different virus species. To reveal such possibility, we performed RT-PCR using heterogous mix of primer pairs and cDNAs. No PCR products were obtained indicating that nucleotide sequences for conserved viral proteins are highly diverse among virus species or genus (data not shown). The majority of imported plants are seeds which might be infected with quarantine plant viruses. Thus, the designed RT-PCR primer pairs could be applied to detect quarantine plant viruses in imported seeds. For that, we are now performing experiments including infection of quarantine viruses into seeds of various host plants and developing techniques to detect viruses in seeds with high sensitivity and simplicity. A previous study demonstrated real time RT-PCR based approach could 


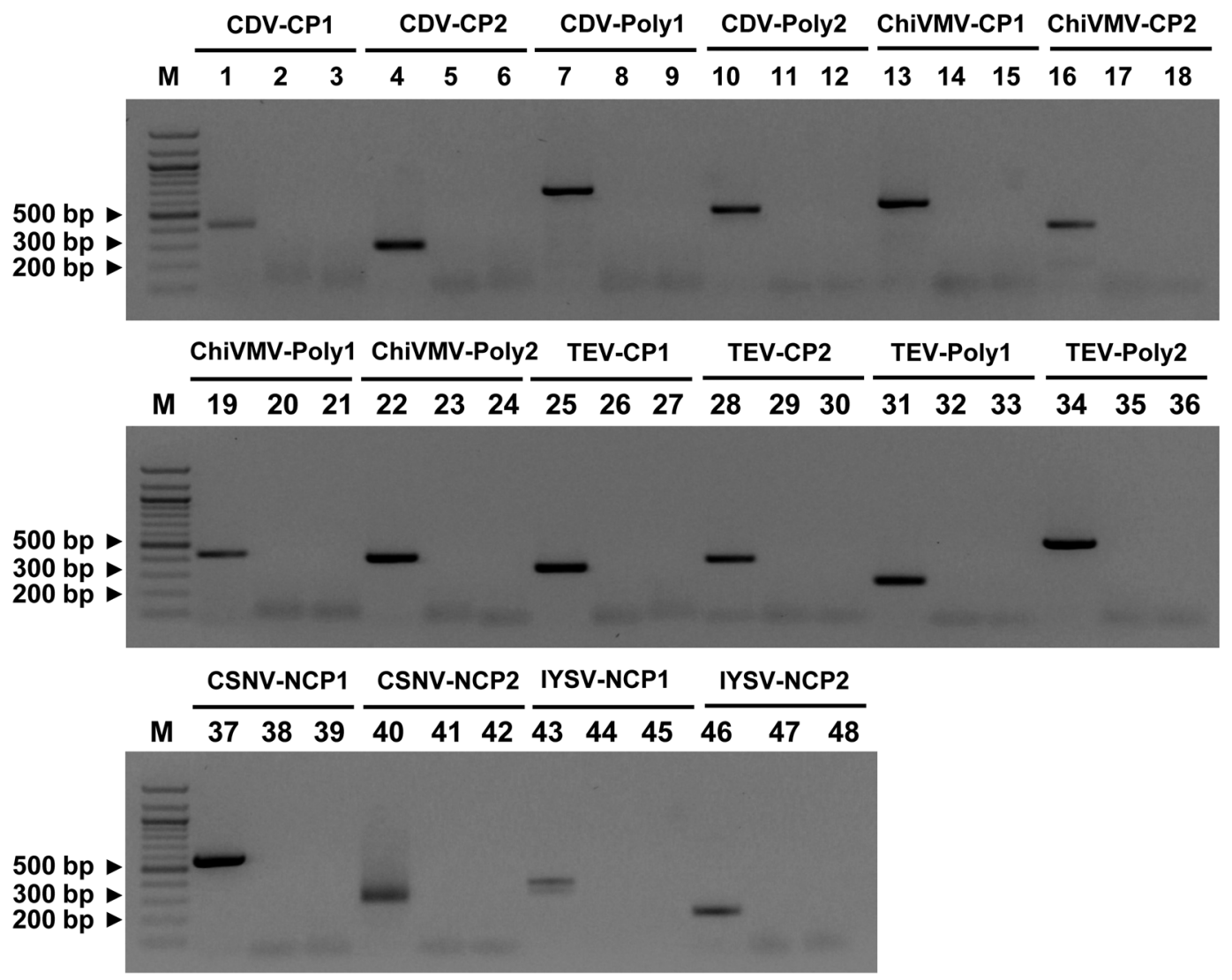

Fig. 3. Specificity of newly designed primers for virus detection by RT-PCR. M indicates 100 bp DNA ladder purchased from NEB, UK. Total RNAs from virus infected (lanes $1,4,7,10,13,16,19,22,25,28,31,34,37,40,43$, and 46), healthy tomato (lanes 2, 5, 8, 11, 14, $17,20,23,26,29,32,35,38,41,44$, and 47 ) and healthy $N$. benthamiana (lanes $3,6,9,12,15,18,21,24,27,30,33,36,39,42,45$, and 48) leaves were used for RT-PCR analyses.

detect Maize chlorotic mottle virus in maize seeds (Zhang et al., 2011).

Although possibility of foreign plant pathogens including viruses, fungi, and bacteria to introduce into Korea is gradually increasing, only a limited number of studies have reported diagnostic system to detect them. For instance, three recent studies developed virus specific primers for RT-PCR based detection (Lee et al., 2004; Lee et al., 2011; Park and Kim, 2004). The first study developed primer pairs to detect seed-transmissible viruses (Lee et al., 2004) while the other studies demonstrated the specificity of designed primer pairs to detect five viruses infecting vegetables and three viruses associated with fruit trees like apple and cherry (Lee et al., 2011; Park and Kim, 2004). In this study, a set of new primers for the detection of five nonreported plant viruses were designed and employed for RTPCR detection. The specificity of each newly designed primer pairs was also evaluated by RT-PCR assay. We identified at least one primer pair which can amplify one specific band for individual plant virus. Moreover, we tested various annealing temperature for PCR and high annealing temperature often led to increase the amount of PCR products and specificity. As compared to our previous study (Lee et al., 2011), we provide more primer pairs to detect each virus and the specificity of designed primer pairs were dramatically increased with $93.75 \%$. The successful application of newly developed RT-PCR primer pairs will be usefully used to detect five quarantine plant viruses.

So far, except RT-PCR, various methods are being applied to detect viruses such as antibodies based enzymelinked immunosorbent assay (ELISA) and electron microscopy. For instance, antibodies generated from recombinant proteins or synthetic polypeptides could successfully detect Rice stripe virus in rice and weed plants (Lian et al., 2011). Moreover, antibody based immunocapture reverse transcription-polymerase chain reaction (IC-RT-PCR) method has shown to be more sensitive method than ELISA or dot-blot immunobinding assay (Sreenivasulu and Sai Gopal, 2010). It is known that many viruses are transmitted by seeds. Generally, to detect viruses in seeds, seeds were first planted in a controlled green house and virus symptoms could be observed. However, such approach requires time and labor. 
Therefore, direct RT-PCR detection method which is precise and efficient could complement such problem. In addition, real-time PCR assay is recently regarded as the next favorable technique because of its high sensitivity (Harper et al., 2011; Zhang et al., 2011). A previous study has shown that $4 \mathrm{fg}$ of total RNA or 25 copies of RNA transcripts are high enough to detect virus and sensitivity of this method seems to be ten-fold higher than other RT-PCR gel electrophoresis approach (Zhang et al., 2011). Therefore, it could be of interest to develop detection system based on real time RT-PCR in near future. In summary, this study provides a useful protocol to detect five ssRNA viruses rapidly for quarantine purpose.

\section{Acknowledgments}

This research was supported in part by grants from the Korea Institute of Planning and Evaluation for Technology of Food, Agriculture, Forestry and Fisheries (No. 30901504); the Vegetable Breeding Research Center (No. 71000103) through Agriculture Research Center program; and the Next-Generation BioGreen 21 Program (No. PJ00819801), Rural Development Administration, Republic of Korea. JSL and WKC were supported by the fellowships from the MEST through Brain Korea 21 Project.

\section{References}

Bezerra, I. C., Resende, R. O. de., Pozzer, L., Nagata, T., Kormelink, R. and Avila, A. C. De. 1999. Increase of tospoviral diversity in Brazil with the identification of two new tospovirus species, one from chrysanthemum and one from zucchini. Phytopathology 89:823-830.

Carrasco, P., Daros, J. A., Agudelo-Romero, P. and Elena, S. F. 2007. A real-time RT-PCR assay for quantifying the fitness of tobacco etch virus in competition experiments. J. Virol. Methods 139:181-188.

Choi, M.-Y., Lee, S.-G., Kim, K.-H., Park, H.-H. and Kim, J. J. 2009. Recent outbreak of insect pests and climate change in Korea. International symposium on climate change and insect pest 3-304.

Diaz-Montano, J., Fuchs, M., Nault, B. A., Fail, J. and Shelton, A. M. 2011. Onion thrips (Thysanoptera: Thripidae): A global pest of increasing concern in onion. J. Econ. Entomol. 104:113.
Elena, S. F., Bedhomme, S., Carrasco, P., Cuevas, J. M., de la Iglesia, F., Lafforque, G., Lalic, J., Prosper, A., Tromas, N. and Zwart, M. P. 2011. The evolutionary genetics of emergin plant RNA viruses. Mol. Plant-Microbe. Interact. 24:287-293.

Garrett, K. A., Dendy, S. P., Frank, E. E., Rouse, M. N. and Travers, S. E. 2006. Climate change effects on plant disease: Genomes to ecosystems. Annu. Rev. Phytopathol. 44:489509.

Harper, S. J., Delmiglio, C., Ward, L. I. and Clover, G. R. 2011. Detection of tomato black ring virus by real-time one-step RTPCR. J. Virol. Methods 171:190-194.

Hwang, J., Li, J., Liu, W. Y., An, S. J., Cho, H., Her, N. H., Yeam, I., Kim, D. and Kang, B. C. 2009. Double mutations in eIF4E and eIFiso4E confer recessive resistance to Chilli veinal mottle virus in pepper. Mol. Cells 27:329-336.

Lee, J.-S., Cho, W. K., Lee, S.-H., Cho, H.-S. and Kim, K.-H. 2011. Development of RT-PCR based method for detecting five non-reported quarantine plant viruses infecting the family Cucurbitaceae or Solanaceae. Plant Pathol. J. 27:93-97.

Lee, B. Y., Lim, H. R., Choi, J. Y. and Ryu, K. H. 2004. Development of molecular detection of three species of seed-transmissible viruses useful for plant quarantine. Plant Pathol. J. 20: 302-307.

Lian, S., Jonson, M. G., Cho, W. K., Choi, H.-S., Je, Y. H. and Kim, K.-H. 2011. Generation of antibodies against Rice stripe virus proteins based on recombinant proteins and synthetic polypeptides. Plant Pathol. J. 27:37-43.

Park, M.-R. and Kim, K.-H. 2004. RT-PCR detection of three non-reported fruit tree viruses useful for quarantine purpose in Korea. Plant Pathol. J. 20:147-154.

Pappu, H. R., du Toit, L. J., Schwartz, H. F. and Mohan, S. K. 2006. Sequence diversity of the nucleoprotein gene of iris yellow spot virus (genus tospovirus, family bunyaviridae) isolates from the western region of the united states. Arch. Virol. 151:1015-1023.

Salamon, P. and Palkovics, L. 2005. Occurrence of Colombian datura virus in Brugmansia hybrids, Physalis peruviana 1. and Solanum muricatum Ait. in Hungary. Acta Virol. 49:117-122.

Sreenivasulu, M. and Sai Gopal, D. V. R. 2010. Development of recombinant coat protein antibody based IC-RT-PCR and comparison of its sensitivity with other immunoassays for the detection of papaya ringspot virus isolates from India. Plant Pathol. J. 26:25-31.

Zhang, Y., Zhao, W., Li, M., Chen, H., Zhu, S. and Fan, Z. 2011. Real-time taqman RT-PCR for detection of maize chlorotic mottle virus in maize seeds. J. Virol. Methods 171:292-294. 